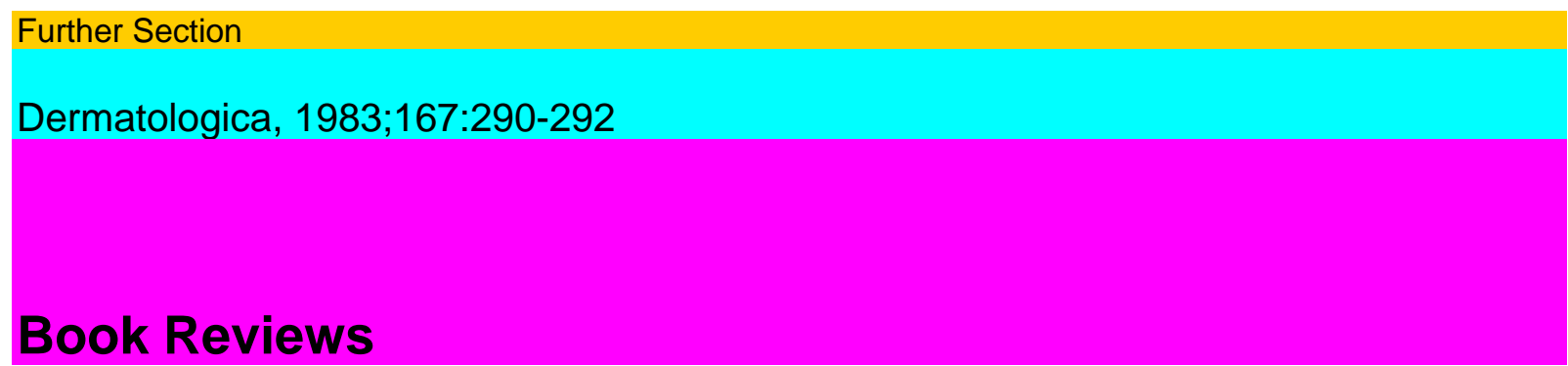

\title{
F.S. Gschnait
}

Orale Photochemotherapie

Grundlagen, Klinik, Praxis, Forschung Springer, Wien 1982184 pp., DM 88.-1SBN 3-21181702-6

Es ist sehr begrüssenswert, dass «ein Mann der ersten Stunde» seine mehrjährigen Erfahrungen mit der oralen Photochemotherapie bekanntmacht. Diese Therapie-form hat ja die dermatologischen Behandlungsmöglich-keiten durch eine neue Dimension bereichert und ist heute aus der dermatologischen Praxis nicht wegzuden-ken. In dem hervorragend ausgestatteten Büchlein wer-den zunächst die biologischen und physikalischen Grundlagen der Photochemotherapie dargestellt, die Apparate, die zur Bestrahlung verwendet werden kön-nen, beschrieben, und dann die einzelnen Indikationen für die orale PU VA besprochen. Dabei werden Wirkun-gen und Nebenwirkungen kritisch gegeneinander abge-wogen, so dass sich der Leser ein klares Bild über Nutzen und Risiko der Behandlung machen kann. Auch zusätz-liche Behandlungsformen wie die Verwendung der Re-tinoide zusammen mit PUVA werden erwähnt. In ei-nem Schlusskapitel werden Vorschläge für die prakti-sche Durchführung der PUVATherapie in grösserem Rahmen gemacht. Es liegt damit ein Buch vor, das jeder Dermatologe, sei er in der Praxis oder noch in der Aus-bildung, durchgearbeitet haben sollte.

R. Schuppli, Basel

C. Duraffourd, L. d'Hervicourt,

J.C. Lapraz

Phytothérapie et dermatologie

Sixième Congrès International de la Société Françai-

se de Phytothérapie et d'Aromathérapie Masson,

Paris 1982

$222 \mathrm{pp}$.

ISBN 2-225-78243-1

Phytothérapie et dermatologie, publié sous le direction de C. Duraffourd, L. d'Hervicourt et J.C. Lapraz a le label de qualité Masson pour la typographic et la mise en page des textes. Pour son contenu, il a la fraîcheur de l'irrationnel où le bon voisine trop souvent avec le mediocre. Le terme «dermatologie» utilise dans le titre de cet ouvrage n'a de toute evidence pas la même signification que celle qu'on lui accorde dans les traités mo-dernes. La quantité de contre-vérités et d'élucubrations fantaisistes que peut contenir ce livre en fait un ouvrage anachronique et par là même presque unique dans la dermatologie de ces dernières années. Si ce livre contient bon nombre d'idées irrationnelles dont les médecins de-vraient se garder, le lecteur peut cependant prendre plai-sir à se croire revivre au siècle de Molière. Ce livre peut done être conseillé à celui qui aura la patience de disséquer cet ouvrage pour en séparer Futile du désuet. Si vous reprenez les paroles d'Hippocrate dans son Traité de $\Gamma$ ancienne Médecine: «le meilleur est ce qui est le plus éloigné du nuisible», cet ouvrage réussit à en faire 
une synthèse qui est soutenue par un style de presentation et une manipulation des plus elegantes de la langue française.

G.E. Pierard et Ch. M. Lapiere, Liège

J.P. Nater, A.C. De Groot

Unwanted Effects of Cosmetics and Drugs Used in

Dermatology

Excerpta Medica, Amsterdam 1983483 pp.; US\$ 106.50/ Dfl. 250.-ISBN 0-444-90265-1

Dermatologists are confronted every day with the side effects of topical drugs and cosmetics. Information on these adverse reactions are scattered over many journals. It is often only the worker in a well-equipped institution who is able to tackle the problem in depth. Nater, de Groot and Liem's book provides us with a marvellous compilation of this kind.

The book opens with 30 pages on definitions, patch-testing techniques and an admirable list of cross-sensitizing compounds. Local side effects of topical drugs follow next. These are listed in 11 chapters according to the type of skin eruption: allergic, phototoxic and photoall-ergic contact dermatitis, contact orticaria, necrosis, fol-liculitis, discoloration, stinging sensations. One chapter Book Reviews

291

is devoted to orally applied medication and one to side effects of corticosteroids.

In a section on systemic side effects of topical drugs, the toxic effects of 35 topically applied compounds are enumerated. There is a chapter on eczematous dermatitis induced by systemic drugs, a chapter on the effects of photochemotherapy and a chapter on the side effects of systemic drugs that are used by dermatologists.

The last half of the book is entirely devoted to the side effects of cosmetics. They are classified according to their use: hair, face, nails, body, etc. There is a chapter on plant products and a chapter on ingredients in cosmetics consisting of a table of 150 pages.

The vast information is made readily accessible to the reader by the logical division of the chapters and the clear composition of the numerous tables. Further tables give additional practical information for patch testing. At least one reference is given for each item. The book can be heartily recommended for daily use by every dermatologist.

E. Van Hecke, Schelderode

R. Brandau, B.H. Lippold

Dermal and Transdermal Absorption, vol. 4

Wissenschaftlicher Verlag, Stuttgart 1982

257 pp.; DM 88.-

ISBN 3-8047-0651-7

The book reflects a review of the current state of the entire field of the external application of drugs and demonstrates the boundaries between confirmed results and as yet unexplored areas of research. It publishes the lectures held from 12-14 January 1981 in Munich during the 1st Symposium on Dermal and Transdermal Absorption, organised by the International Association for Pharmaceutical Technology. As the title suggests, two distinct parts are taken into account by the lectures given by specialists in that field. Nine of them are dealing with dermal (i.l. topical) preparations and three reflect transdermal absorption (with systemic effects).

In the first part are reported (1) the classification of agents used in dermatology by C. Führer, (2) drug absorption by intact and damaged skin by G. Stiittgen, (3) mechanism of penetration of drugs into the skin by W. Schalla and H. Schaefer, (4) the influence of the vehicle on the 
absorption and permeation of drugs by J. Ziegenmeyer, (5) in vitro drug release form ointments and creams, by T. Higuchi, (6) in vitro methods for stimulating the absorption of drugs by B.H. Lippold, (7) methods for evaluation of drug concentration in human

skin by A. Zesch, (8) metabolism of drugs on and in the skin by U. Täuber and (9) toxiclogical aspects of local application by F.H. Kemper.

The second part of the lectures is dealing with (10) possibilities and limitations of transdermal absorption by A.H. Beckett, (11) transdermal therapeutic systems by J.E. Shaw and (12) industrial development of transdermal therapeutic systems by A. Zaffaroni.

The texts of the lectures are followed by requirements for topical preparations by the Health Authorities in Great Britain, Sweden, Switzerland, the USA and the Federal Republic of Germany.

All lectures are followed by a discussion and references are given to the literature.

As R. Brandau declares in the introduction and what indeed can be deduced by reading the different lectures 'an intensive teamwork is necessary between workers engaged in the fields covered by this symposium. This is clearly illustrated by the fact that among the invited speakers were pharmacists, dermatologists, biochemists, chemist pharmacologists and toxicologists. Only by such cooperation between disciplines can we hope to make progress in dermatological therapy, in the transdermal treatment of systemic diseases and in cosmetics'. In another passage of that introduction is said that 'this symposium did not attempt to draw preliminary line underneath a successful development, but rather tried to more clearly define the points from which future research will start and indicate its aims, which will take many years to fulfill'. After taking cognizance of the contents of the book the reviewer can fully agree with that assertion.

A round table discussion is reported at the end of the paperback dealing with a uniform system of nomenclature, the use of the term bioavailability related to dermal preparations, the sort of tests that would be needed to study the actual bases, if in vitro tests are meaningful or not why animal experiments are required if they are not comparable or relevant to the clinical situation and if results from animal experiments really can be extrapolated to man, and finally, considerations on the enzymatic activity of the skin, a problem that must be investigated more intensively in order to know if truly metabolic processes or simple chemical degradations take place.

A survey of posters giving some insight into research work in the field of dermal products and preparations is also reproduced. Pharmacists, dermatologists, regulatory authorities as well as members of university research and education departments, pharmaceutical and cos-

292

Book Reviews

metic industries can benefit from the extremely interesting data of the book.

The International Association for Pharmaceutical Technology and the chairmen R. Brandau and P. Reisen of the symposium are to be congratulated for the initiative. The paperback fills up a gap and can be warmly recommended.

P. Braeckman

Robert M. Adams Occupational Skin Disease

Grune \& Stratton, New York 1983 XIII+ 477 pp.; US 69.50 ISBN 0-8089-1494-4

The book starts with 6 chapters on the clinical picture of occupational skin disease, including dermatitis, diseases due to physical factors and infections, contact urticaria, acne, skin cancer and nail disorders. The middle section (chapters 7-10) is dedicated to diagnosis, patch testing in particular, treatment, prevention, and -rather inapplicable for physicians outside the USA - 
medicolegal aspects. The last 9 chapters cover the industrial products, their chemical composition, use and adverse effects on the skin. A 70 pages long appendix enumerates the irritants and allergens of the various occupations with comprehensive suggestions for patch testing.

Dr Adams' book is a very useful tool in the management of occupational skin disease. It should be continuously consulted by everyone dealing with skin disease probably related to occupation. E. Van Hecke, Schelderode

Mark V. Dahl

Common Office Dermatology

Grune \& Stratton, New York 1983 XII + 173 pp. ISBN 0-8089-1497-9

To the dermatologist nurtured on the classical textbooks, the title of the first chapter of this book: 'How to select a topical corticosteroid' comes as a shock. But when one reads the preface, one becomes aware that this is not a textbook intended for dermatologists: 'This is a basic book . . . most of the skin problems confronting primary care physicians can be covered in a small book. This is such a book; it was written to be read ... This

book stresses diagnosis and easy classifications leading to rational prescribing. Treatments are presented in detail

The book itself consists of 20 chapters, ranging from therapeutic principles to 'sun and skin', over psoriasis, hand eczema, alopecia, common groin eruptions, etc.; these are revisions of articles that have appeared in Modern Medicine over the past 5 years. Approximately 80 colour pictures illustrate the text and most of them are excellent. The book is rather slim, even more than the number of pages indicates: there are 50 pages left blank between the chapters.

The good intentions set out in the preface are not always realized: in some places only US trade names are given and not the generic names of drugs, and in the chapter on 'Diffuse nonscarring alopecia' treatment is entirely lacking. On the other hand, I subscribe to the statement that 'the key to successful management of leg ulcerations is not topical therapy' and to the general comment of a senior medical student who read it that it was 'really captivating'.

J. De Bersaques, Schelderode

G.W. Korting

Praxis der Dermatologie

Ein Lehrbuch für die Aus- und Weiterbildung Thieme, Stuttgart 1982446 pp., 470 fig.; DM 148.-ISBN 3-13-616401-6

Wie nicht anders zu erwarten, stellt auch diese «Pra-xis» ein äusserst gut gelungenes Werk dar. Als Extrakt aus dem vierbändigen Werk «Dermatologie in Praxis und Klinik» bringt es die praktisch wichtigsten Krank-heitsbilder in kurzer und knapper Form, wobei er-staunlich viel Information an dermatologischem Grundwissen geboten wird. Aber auch die selteneren Krankheiten werden erwähnt, so dass das Buch eine umfassende Orientierung über die Erscheinungsvielfalt der Hautveränderungen vermittelt. Der Text ist mit durchwegs hervorragenden farbigen Abbildungen illu-striert. Die therapeutischen Empfehlungen sind knapp gehalten und erlauben eine zweckmässige, praxisgerech-te Behandlung. Das Buch kann sowohl dem dermatologischen Neuling als auch dem bestandenen Praktiker empfohlen werden, kann aber auch für den Studenten, der später keinen dermatologischen Unter-richt mehr erhält, als Orientierungsbuch von bleiben-dem Wert sein.

R. Schuppli, Basel 